\title{
The Flipped Classroom: A Comparison of Student Performance Using Instructional Videos and Podcasts versus the Lecture-Based Model of Instruction
}

\author{
Retta Guy and Gerald Marquis \\ Tennessee State University, Nashville, Tennessee, USA
}

\section{rguy@tnstate.edu; gmarquis@tnstate.edu}

\begin{abstract}
The authors present the results of a study conducted at a comprehensive, urban, coeducational, land-grant university. A quasi-experimental design was chosen for this study to compare student performance in two different classroom environments, traditional versus flipped. The study spanned 3 years, beginning fall 2012 through spring 2015. The participants included 433 declared business majors who self-enrolled in several sections of the Management Information Systems course during the study. The results of the current study mirrored those of previous works as the instructional method impacted students' final grade. Thus, reporting that the flipped classroom approach offers flexibility with no loss of performance when compared to traditional lecturebased environments.
\end{abstract}

Keywords: flipped classroom, instructional videos, podcasts, student performance, traditional lecture, video-recorded lectures

\section{Introduction}

As the new millennium is well underway, colleges and universities are challenged to meet the demands of the 21 st century student with learning environments that are student centered, selfdirected, technology enhanced, and flexible (Flumerfelt \& Green, 2013). The millennials, hailed as the most technologically savvy students of this century, have forced educators to examine new instructional methods that incorporate the use of technology. To meet such demands, the flipped classroom has emerged as a viable alternative to the traditional, lecture-style teaching and learning (Bishop \& Verleger, 2013). Catalyzing change in the physical classroom, the flipped (or inverted) instructional method offers "a mix of diverse content via the combined technological capabilities of the Internet, high performance computing, advanced networking, in-home electron-

Material published as part of this publication, either on-line or in print, is copyrighted by the Informing Science Institute. Permission to make digital or paper copy of part or all of these works for personal or classroom use is granted without fee provided that the copies are not made or distributed for profit or commercial advantage AND that copies 1) bear this notice in full and 2) give the full citation on the first page. It is permissible to abstract these works so long as credit is given. To copy in all other cases or to republish or to post on a server or to redistribute to lists requires specific permission and payment of a fee. Contact Publisher@,InformingScience.org to request redistribution permission. ics, and mobile communication" (National Science Foundation, 2008, p. 6).

Butt (2014) asserts that,with the flipped classroom, instructional materials such as video recorded lectures, PowerPoint presentations and podcasts are delivered outside the traditional classroom setting, therefore, collaborative and interactive activities are completed during the formal class time. Similarly, Bishop and 
Verleger (2013) describe the flipped classroom as an educational technique whereby interactive group learning activities take place inside the classroom while the direct computer-based individual instruction is accessed outside the classroom. Poon (2013) further describes the flipped classroom instructional method as "a mix of pedagogical approaches that combines the effectiveness and the socialization opportunities of the classroom with the technological enhancements of online learning" (p. 18).

There are a number of studies that have reported student success and increased engagement in the flipped classroom. Proponents argue that the flipped classroom approach fosters student participation and active learning, creates opportunities for critical thinking, and embraces interactive technologies to deliver instruction (Hamdan \& McKnight, 2013). Kathleen Fulton (2012) further claims that this approach explicitly improves student learning and enhances social skills. Pierce and Fox (2012) suggest that the flipped classroom facilitates the development of students as active learners rather than passive receptacles of information and transforms the role of the instructor from "being dispensers of facts to being architects of learning activities" (p. 22). Additionally, students benefit from the flipped approach as it encourages self-pace learning, increases studentinstructor interaction, and permits access to instructional materials on-demand (Smith, 2013).

Despite the stated advantages and benefits of the flipped classroom as an instructional strategy, there are a number of concerns voiced by its critics. First, many educators feel as though the flipped classroom undervalues face-to-face socratic teaching, thus creating an environment whereby the instructor no longer provides engaging lectures but "leads from behind" while assuming the tasks of observation, feedback, and assessment (Marshall, 2013). Secondly, while home access to computers and the Internet has expanded over the past couple of decades, there is still a large percentage of students who are impacted by the digital divide and consequently are not able to access required digital content such as video lectures, annotated PowerPoint presentations, and other electronic materials necessary for student development and learning (Hamdan \& McKnight, 2013). Finally, there is lack of consensus as to the design and structure of a flipped classroom as well as an insufficient amount of scholarly research regarding its effectiveness relative to student performance (Bishop \& Verleger, 2013).

Educators and researchers alike are actively debating whether students in the traditional lecturebased environment perform equal to or better than students in the flipped classroom. Accordingly, the current study represents the findings of academic performance of students in the traditional class sections of an undergraduate management information systems course compared to those in the flipped class sections.

\section{Literature Review}

A review of literature reports on a number of research studies that have provided comparable data on student performance between traditional and flipped classroom environments. Specifically, the authors examined 10 parallel studies for inclusion in this review, 5 of which found more favorable results with the flipped approach, 1 found the reverse with higher performance scores in the traditional method of instruction, 3 confirmed a non-significant difference, and 1 reported mixed results. The current review also reports on 16 studies that examined the use of visual media (such as videos, podcasts, and vodcasts) to deliver instructional content.

\section{Comparing Student Performance}

A number of researchers have compared student performance in traditional versus flipped classrooms and found that students in the flipped learning environment often outperformed those in the traditional lecture-based classes. For instance, Alvarez-Bell (2014) conducted a pilot study in which she compared the academic performance of students enrolled in an advanced general 
chemistry course. The study participants included 84 students from 17 different majors and class statuses ranging from freshman to graduate. Three sections of advanced general chemistry were offered, each taught by a different instructor. Two sections (1 and 2) followed the traditional lecture-based format and the third section was redesigned based on the flipped classroom method. At the end of the semester, all study participants were administered the American Chemical Society comprehensive standardized final exam. The results revealed that the flipped section had the largest percentage of students with an exam grade of $\mathrm{C}$ or higher $(86 \%)$ compared to the traditional lecture section $1(72 \%)$ and the traditional lecture section $2(61 \%)$.

The purpose of the study conducted by Tune, Sturek, and Basile (2013) was to assess and compare student performance in a traditional lecture-based curriculum versus a modified flipped classroom curriculum of cardiovascular, respiratory, and renal physiology delivered to first-year graduate students. Those enrolled in the modified flipped classroom (1) watched pre-recorded lectures prior to class and (2) completed group activities, individual assignments, and quizzes during class followed by a question and answer/problem solving period. In the traditional curriculum, attending face-to-face lectures was required and individual assignments and activities were assigned as homework. Students in both courses were administered the same multiple-choice exam with those in the flipped classroom curriculum scoring significantly higher on the cardiovascular and respiratory sections by an average of 12 percentage points and by 11 percentage points on the renal section.

Ruddick (2012) compared final exam scores and overall grade averages of students enrolled in a traditional lecture-based section of an introductory chemistry course with those enrolled in the redesigned flipped version of the same. Students in the traditional section received lectures during class time and completed individually-based activities at home while those in the flipped section watched video lectures at home and spent class time working on problem-based activities. Results showed that students in the flipped section outperformed their counterparts in the traditional lecture-based section with higher final exam scores and a larger percentage earning an overall grade of C or better. Similarly, Strayer (2012) performed a comparative analysis between the flipped and traditional classroom of an introductory statistics course and found that students in the flipped section demonstrated more innovation and cooperation in their learning when compared to students in the traditional section.

Papadopoulos and Roman (2010) applied the flipped learning model where lecture materials were delivered before class and students completed guided work during class meetings in an electrical engineering course. The same course was offered in a traditional format where lecture was delivered during class and problem solving activities were assigned as homework. Pre- and post-test scores were used to compare student performance between the traditional and flipped classes. A non-significant difference was found when examining the results of the pre-test with the flipped class answering $18.3 \%$ of the questions correctly and those in the traditional class answering $17.1 \%$ correctly. With the posttest, the differences were significant with students in the flipped class answering $31.2 \%$ of the questions correctly compared to those in the traditional class answering $24.1 \%$ correctly.

Bishop and Verleger (2013) provide anecdotal evidence suggesting that student learning is improved in the flipped compared to the traditional classroom. On the other hand, Berrett (2012) and Lape, Levy, and Yong (2014) suggest that converting to the flipped classroom model is labor intensive and does not necessarily show better student performance than the traditional classroom environment. For instance, in the study conducted by Frederickson, Reed, and Clifford (2005), when comparing student experiences and academic performance in the traditional versus the flipped classrooms, students in the latter environment were less satisfied with the course structure and the authors found no significant difference in students' knowledge by the end of the course. Student comments indicated that they were dissatisfied with the web-based lectures because the 
instructional materials did not provide illustration of content but found the peer collaboration to be more thought-provoking and exciting.

In examining the performance of students in the flipped classroom versus the traditional face-toface model, Johnson and Renner (2012) compared test scores of students in both groups enrolled in a computer applications course. The authors found no significant differences between mean test scores of those who experienced the flipped classroom and those students in the traditional face-to-face format. This study was repeated in a secondary applications course and the results were the same. Additionally, the study conducted by Strayer (2012) echoed similar results when he compared the learning environments of an inverted (flipped) introductory statistics class with a traditional introductory statistics class.

\section{Using Instructional Videos and Podcasts}

The teaching methodology for the flipped classroom involves providing instructional resources and materials for students to access before class, which may include video-recorded lectures, discipline-specific online videos, audio-visual recorded podcasts sessions, and electronic articles (Enfield, 2013; Roehl, 2013). These methods can be employed by videotaping the instructor while lecturing, utilizing existing discipline-specific videos from sources such as YouTube and/or Teacher Tube, developing audio-visual files that can be distributed via the Internet, or by providing online access to journal articles (Bergmann \& Sams, 2012; McGarr, 2009; Roehl, 2013).

Milman (2012) explains "the idea is that rather than taking up valuable class time for an instructor to introduce a concept (often via lecture), the instructor can create a video lecture, screencast, or vodcasts that teaches students the concept, freeing up valuable class time for more engaging (and often collaborative) activities typically facilitated by the instructor" (p. 85).

The use of visual media such as videos, podcasts, and vodcasts has become a viable pedagogical option to access instructional content as it supports a self-directed, student-centered approach to learning (Burke \& Cody, 2014). In addition to visual media, technology and social media are being used to meet student needs and to improve academic performance in a flipped classroom environment (Bergmann \& Sams, 2012; Franciszkowics, 2008).

Educators cite the following advantages in using visual media to deliver instructional content in a flipped classroom: (a) access to material on demand; (b) access of content via mobile devices, (c) quick dissemination, consistency, and updates of content, (d) distribution to a wide audience, and (e) accommodation of varied learning styles/preferences (Long \& Edwards, 2010).

On the other hand, opponents of the flipped classroom approach offer potential pitfalls in delivering instructional content via visual media as (a) it can become labor intensive and time consuming for faculty in creating video content; (b) it can cause students to feel a sense of abandonment in having to learn content on their; and (c) it can incite culture shock for those students accustom to an educational environment of traditional lectures (Talbert, 2012). Other concerns as noted by Milman (2012) include poor quality instructional design and video production; inadequate technology coupled with unfavorable environments in which students view videos; challenges faced by second language learners and students with learning disabilities; and the inability to monitor student comprehension and provide timely feedback.

Studies on the use of videos and podcast to deliver instructional content support similar findings. Kay and Kletskin (2012) developed a series of video podcasts for a first year undergraduate calculus course. A custom-designed tracking device showed that the majority of students viewed the video podcasts frequently, with a reported 4,500 views within a 21-day period. Data collected from an open-ended survey indicated that students found the podcasts useful, easy to follow, and effective for learning. 
He, Swenson, and Lents (2012) compared student performances in an undergraduate analytical chemistry course whereby the experimental group received access to video-recorded lectures and the control group received the traditional face-to-face instruction. To assess the effectiveness of each content delivery method, students' oral and written feedback, as well as, pre- and posttests were examined. Study results revealed that the video-recorded lectures were a valuable, flexible, and cost effective tool for improving student mastery of chemistry concepts.

Moravec, Williams, Aguilar-Roca, and O'Dowd (2010) conducted a study in which they converted a traditional large-lecture introductory biology course to a flipped classroom to ascertain whether student performance would improve using the latter approach to teaching and learning. In the flipped classroom, students watched pre-recorded videos before class followed by interactive exercises. The study results showed an average increase of $21 \%$ on exam scores for students in the flipped classroom format.

Earlier studies revealed that students found the delivery of instruction through visual media to be an effective method for learning course content, taking notes, and preparing for assessments (Gannod, Burge, \& Helmick, 2008; McGarr, 2009). Additionally, Copley (2007) reported that both undergraduate and graduate students frequently listened to podcasts of lectures as a means to reinforce learning and to gain deeper understanding of course content.

\section{Methodology}

The current study was conducted at Tennessee State University (TSU), a comprehensive, urban, coeducational, land-grant university located in Nashville. A constituent institution of the Tennessee Board of Regents and a Historically Black University, TSU was founded in 1912 and currently serves a growing student population of approximately 9,200. The current study encompasses students from the College of Business at Tennessee State University. The College boasts a student population of 879 of which 797 are enrolled in the undergraduate program and 82 in graduate studies.

A quasi-experimental design was chosen for this study to compare student performance in two different classroom environments: traditional versus flipped. The study spanned 3 years, beginning fall 2012 through spring 2015. The participants included 433 declared business majors who self-enrolled in several sections of Management Information Systems, a required course for all business majors. The demographics of the sample population included a large percentage of African Americans (83\%), both males $(63 \%)$ and females $(37 \%)$, and a mixture of traditional $(71 \%)$ and non-traditional (29\%) students.

The traditional and flipped course sections were run consecutively and were facilitated by the same professor who holds a Ph.D. in Management Information Systems as well as an MBA in the same field along with a Master's in Education.

All sections for both the traditional and flipped classes were full 16-week semesters and met faceto-face for 2.5 hours per week. All sections used the same textbook and covered the same chapters in the same order. Students received access to additional resources and self-assessment quizzes through the course adopted book publisher's educational portal website.

In the traditional sections, students were required to read textbook chapters and complete homework assignments prior to class while the professor taught course content by lectures with the use of PowerPoint presentations during class. The classroom structure was inverted for students enrolled in the flipped sections. Brief, but comprehensive, video lessons provided by the book publisher and discipline-specific podcasts selected from an online repository were made available to and viewed by students prior to the class session, while in-class time was devoted to exercises, 
group projects, and discussions (see Table 1 for classroom structure of both the traditional and flipped environments).

Table 1: Class Structure for Traditional and Flipped Classrooms

\begin{tabular}{|l|l|l|}
\hline Style & During Class & Prior to Class \\
\hline Traditional & $\begin{array}{l}\text { Lectures w/PowerPoint Presenta- } \\
\text { tions } \\
\text { Quizzes/Exams }\end{array}$ & Activities/Projects \\
\hline Flipped & $\begin{array}{l}\text { Discussion } \\
\text { Group Activities/Projects } \\
\text { Quizzes/Exams }\end{array}$ & $\begin{array}{l}\text { Video Lessons } \\
\text { Podcasts }\end{array}$ \\
\hline
\end{tabular}

The course was composed of seven modules: (1) Introduction to Information Systems, (2) Organizational Information Systems, (3) Networks, E-Business and E-Commerce, (4) Data and Knowledge Management, (5) Customer Relationship Management in Information Systems, (6) Supply Chain in Information Systems, and (7) Ethics, Privacy, and Security Issues.

Course assessment measures for all sections included 5 activities/projects, 7 quizzes, and 2 exams. The activities/projects were designed to reinforce learning and to demonstrate knowledge. In assessing learning, students were required to evaluate software packages, conduct spreadsheet analysis, create queries and reports, create a storyboard that illustrated web building, and identify all upstream units relative to a product in the supply chain. Ten-point quizzes were given at the end of each module and were used as an indicator of individual student success. Lastly, two multiple-choice exams (mid-term and final) were administered to each class. The mid-term consisted of the first three modules which covered learning objectives that focused on different components of a system and the impact of e-commerce, telecommunication and networks on society. The final exam covered the remaining 4 modules with learning objectives that focused on enterprise business systems, transaction processing systems, and customer relationship management.

The Desire2Learn (D2L) learning management system was used for the administration of all quizzes, exams, and submission of written assignments for the traditional and flipped course sections. The final grade averages included activities/projects (25\%), Quizzes (25\%), mid-term exam $(25 \%)$ and final exam $(25 \%)$.

\section{Results}

The performance of the 433 students enrolled in both the traditional and flipped class sections was measured by final grades achieved. This data was analyzed using a cross tabulation to determine any significant differences between the variables, for which Statistical Package for Social Sciences (SPSS) was used with the significance level set at $\mathrm{a}=0.05$.

Data analysis in this study consisted of two phases. In Phase 1, descriptive statistics were used to provide quantitative summaries of each assessment by instructional method as reported in Table 2 . The average activity/project score for the traditional group (88\%) was slightly higher than for the flipped (84\%). Quite the reverse holds true for all other course assessments. The average quiz score for the traditional group was $76 \%$ compared to $79 \%$ for the flipped sections. Similarly, the average exam score for the traditional group was $81 \%$ compared to $88 \%$ for the flipped sections. 
The average score for final grades revealed that students in the flipped class sections performed slightly better $(83 \%)$ than those in the traditional sections $(82 \%)$.

\section{Table 2: Average Scores on Course Assessment}

\begin{tabular}{|l|c|c|}
\hline Course Assessments & Traditional & Flipped \\
\hline Activities/Projects & $88 \%$ & $84 \%$ \\
\hline Quizzes & $76 \%$ & $79 \%$ \\
\hline Exams & $81 \%$ & $88 \%$ \\
\hline Final Grades & $82 \%$ & $83 \%$ \\
\hline
\end{tabular}

Figure 1 illustrates student performance in the Control-Traditional Group with 27.6\% of the study population earning final grades between $90-100 ; 33.3 \%$ earning between $89-80 ; 23.7 \%$ earning between $79-70 ; 8.3 \%$ earning between $69-60$; and 3.5\% earning a final grade of 59 and below. Of the initial enrollment, $8(3.5 \%)$ students withdrew from the Traditional class sections.

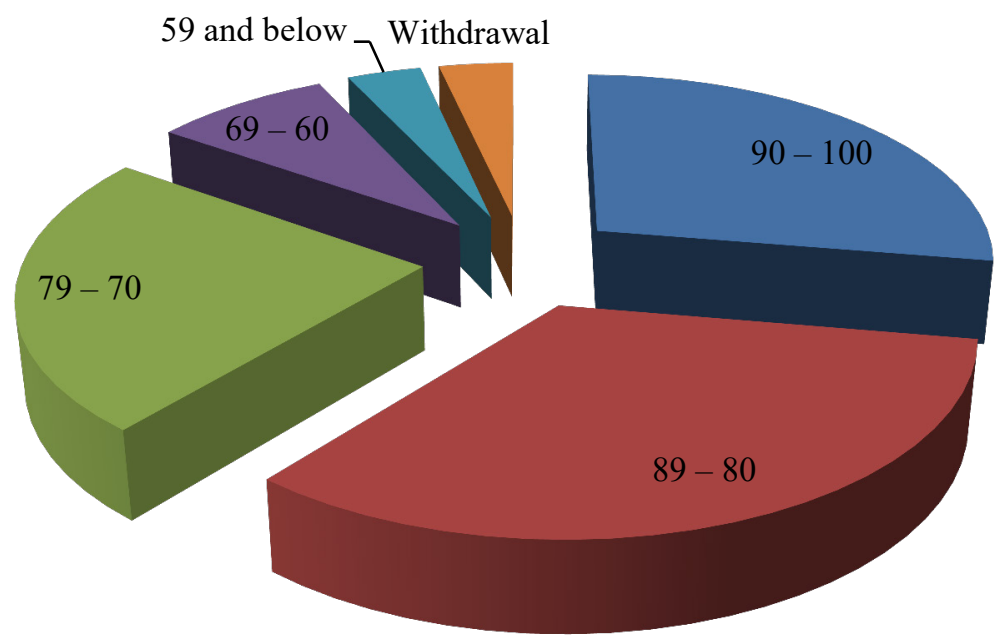

Figure 1: Student Performance of Control--Traditional Group

Figure 2 illustrates student performance in the Experimental-Flipped Group with $40.5 \%$ of the study population earning final grades between $90-100 ; 35.6 \%$ earning between $89-80 ; 13.2 \%$ earning between 79-70; 5.4\% earning between 69-60; and 2.9\% earning a final grade of 59 and below. Only $5(2.4 \%)$ students withdrew from the Flipped class sections. 


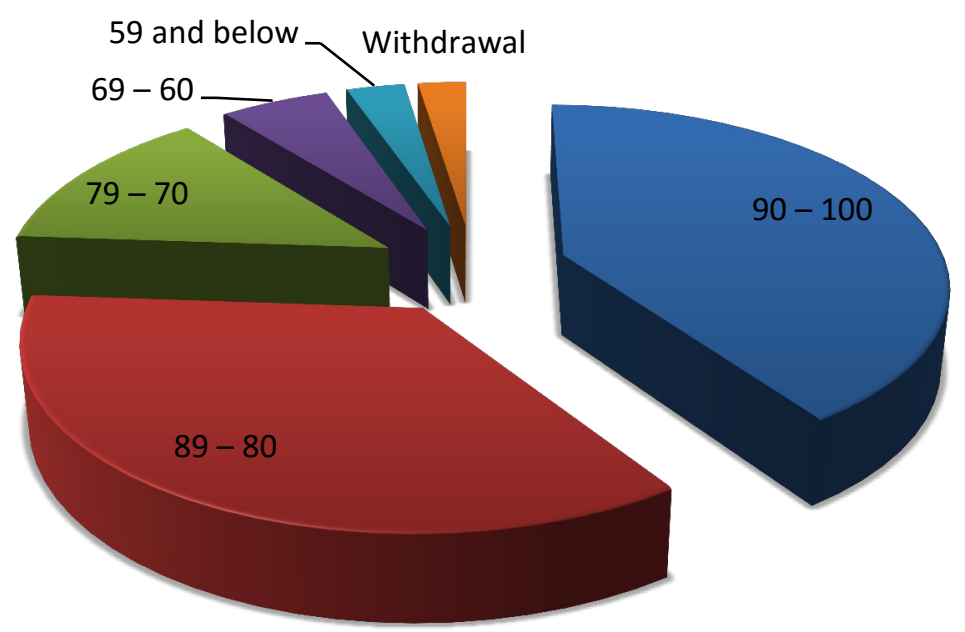

\section{Figure 2: Student Performance of Experimental--Flipped Group}

In the second phase of the data analysis, a cross tabulation of category frequencies and the ChiSquare Test were computed to determine if correlation exists between final grades and the instructional method (traditional versus flipped). The results, as revealed in Table 3, were found to be statistically significant $\mathrm{p}<.05(.017)$, thereby the authors support the claim that the instructional method impacted students final grade and, accordingly, conclude that there is sufficient evidence to assert that a relationship exists between the two variables.

\begin{tabular}{|l|r|r|c|}
\hline \multicolumn{4}{|c|}{ Table 3: Instructional Method Chi-Square Test } \\
\hline & Value & $\mathrm{df}$ & $\begin{array}{c}\text { Asymp. } \\
\text { Sig. }\end{array}$ \\
\hline Pearson Chi-Square & $13.729 \mathrm{a}$ & 5 & .017 \\
\hline Likelihood Ratio & 13.906 & 5 & .016 \\
\hline Linear-by-Linear Association & 8.783 & 1 & .003 \\
\hline N of Valid Cases & 433 & & \\
\hline
\end{tabular}

a. 0 cells $(.0 \%)$ have expected count less than 5 . The minimum expected count is 6.15 .

In order to garner feedback with regard to student satisfaction in both the traditional and flipped classrooms, students were asked to evaluate the course. An online survey was administered at the end of each semester with 215 students participating in the evaluation process (56-traditional and 159-flipped).

Cross tabulations were run in order to determine student satisfaction between course designs (traditional and flipped). The first cross tabulation looked at responses to the statement "My knowledge of the subject increased as a result of this course." The findings, as displayed in Table 4 , indicate that the majority of students in both the traditional (94\%) and flipped (87\%) format either 'strongly agreed' or 'agreed' the class increased their knowledge of the subject. 


\section{Table 4: Student Satisfaction between Course Designs}

\begin{tabular}{|l|r|r|r|r|r|r|}
\hline & $\begin{array}{c}\text { Strongly } \\
\text { Agree }\end{array}$ & Agree & Neither & Disagree & $\begin{array}{c}\text { Strongly } \\
\text { Disagree }\end{array}$ & $\begin{array}{c}\text { Total Re- } \\
\text { spondents }\end{array}$ \\
\hline \multicolumn{7}{|c|}{ "My knowledge of the subject increased as a result of this course." } \\
\hline Traditional & $66.1 \%$ & $28.6 \%$ & $3.6 \%$ & $1.8 \%$ & $.0 \%$ & 56 \\
\hline Flipped & $64.2 \%$ & $22.6 \%$ & $9.4 \%$ & $1.3 \%$ & $2.5 \%$ & 159 \\
\hline $\begin{array}{l}\text { Total Respond- } \\
\text { ents }\end{array}$ & 139 & 52 & 17 & 3 & 4 & 215 \\
\hline
\end{tabular}

The next cross tabulation looked at responses to the question "How many hours did you spend studying for this course each week?" As shown in Table 5, the majority of students in both the traditional and the flipped sections ( $41.1 \%$ and $44.0 \%$, respectively) spent 3-6 hours studying per week while less than $3 \%$ of the total respondents spent more than 15 hours per week.

\begin{tabular}{|l|r|r|r|r|r|r|r|}
\hline \multicolumn{2}{|c|}{ Table 5: Number of Hours Spent Studying } \\
\hline & $\begin{array}{c}0-3 \\
\text { Hours }\end{array}$ & $\begin{array}{c}3-6 \\
\text { Hours }\end{array}$ & $\begin{array}{c}6-9 \\
\text { Hours }\end{array}$ & $\begin{array}{c}9-12 \\
\text { Hours }\end{array}$ & $\begin{array}{c}12-15 \\
\text { Hours }\end{array}$ & $\begin{array}{c}15+ \\
\text { Hours }\end{array}$ & $\begin{array}{c}\text { Total } \\
\text { Respondents }\end{array}$ \\
\hline \multicolumn{7}{|c|}{ "How many hours did you spend studying for this course each week? } \\
\hline Traditional & $33.9 \%$ & $41.1 \%$ & $16.1 \%$ & $7.1 \%$ & $.0 \%$ & $1.8 \%$ & 56 \\
\hline Flipped & $36.5 \%$ & $44.0 \%$ & $12.6 \%$ & $5.0 \%$ & $1.3 \%$ & $.6 \%$ & 215 \\
\hline $\begin{array}{l}\text { Total Respond- } \\
\text { ents }\end{array}$ & 77 & 93 & 29 & 12 & 2 & 2 & 159 \\
\hline
\end{tabular}

The online survey instrument also included open-ended questions in which students were asked what they liked best about the delivery of instruction and to provide recommendations for course improvement. An abbreviated summary of student responses from the traditional group included the following:

- "No improvement needed, the class was great!"

- "Nothing needs to be done. It's fine as is."

- "Provide videos and other visual aids to assist the class along with PowerPoint slides."

- "The instructor taught in a step-by-step manner which made the criteria easy to comprehend."

- "The instructor explained everything as in the real world."

An abbreviated summary of student responses from the flipped group included the following:

- "The group projects helped me understand the concepts in the textbook. An improvement might be to give more individual assignments to practice what you learned from the group project."

- "The instructor encouraged group assignments, which enabled the learning process. In doing so, if someone in the group did not understand, then another member had the knowledge. If none of us caught on, the instructor was available to answer questions."

- "In-class projects were very helpful. Nothing to improve." 
- "The best thing about the class was the projects that were done in class; so if a question would arise, the instructor would be there to assist. The instructor had multiple forms of teaching: PowerPoint slides, videos, class discussions, and projects. The diversity of teaching approaches made class more enjoyable and engaging. I highly recommend his teaching techniques."

- "The best thing was the group projects. No improvements suggested."

- "I enjoyed watching the videos and podcasts."

Finally, the students in the flipped course sections were asked their preference for course delivery. Of the 100 survey respondents, $17 \%$ preferred the traditional method, $75 \%$ preferred the flipped method, and $8 \%$ would have preferred the fully online method with videos and podcasts.

\section{Discussion}

The results of the current study appear to be consistent with research conducted by Alvaez-Bell (2014), Ruddick (2012), and Strayer (2012) in which students in the flipped class sections outperformed those in the traditional sections. Beyond effects of the flipped classroom relative to academic performance, students' level of commitment and satisfaction is also important. Solicited comments indicate that the majority of students in the flipped group (44\%) dedicated 3-6 hours per week studying course content and materials. The group also found the flipped instructional method to be enjoyable and more responsive to their learning needs.

It is important for students to adapt to the flipped classroom environment in the initial weeks of a course. However, the adaptation period varied for the study population as some students caught on to the format quickly whereas others needed additional time to get in the habit of watching videos and studying course content prior to class time. The initial struggle with the flipped format may explain why the group's average score for the activity/project course assessment (84\%) was slightly lower than the traditional group's (88\%). Table 2 compares the average scores for each course assessment and shows that students in the flipped group performed slightly better on average on quizzes and exams compared to the traditional group.

From a teaching perspective, the flipped format provided more opportunities for interaction between and among students and the instructor. Class time was spent helping students with activities/projects, which allowed for more corrective action whenever students were misguided and reinforcement when learning goals were achieved. As observed by the course instructor, nearly $75 \%$ of the students in the flipped class sections were actively participating in the learning process compared to less than $50 \%$ of the students in the traditional sections. Those enrolled in the flipped sections were engaged during class time and appeared to be very enthusiastic about the subject whereas those in the traditional sections were seemingly less engaged and the majority of the time disinterested in learning the material.

Based on the results and comments from the course evaluations, students in both the traditional and flipped course sections had enjoyable learning experiences, however, those in the latter group provided more positive feedback for in-class group activities/projects and the use of videos and podcasts for instructional purposes. The level of interest experienced from the flipped group was not unexpected as the majority of the students were millennials who possess greater technology know-how compared to the non-traditional student.

In summary, this study sought to determine whether student performance differs based on the instructional method (traditional and flipped). The findings revealed that the instructional method did in fact impact student performance. In likeness to the findings of this study, the reviewed literature reveals a predominance of significant differences found between the two instructional methods (Alvarez-Bell, 2014; Ruddick, 2012; Strayer, 2012; Tune, Sturek \& Basile, 2013). 


\section{Study Limitations}

As with any research, particularly in the area of instructional design, there were a number of limitations that may impact this study; accordingly, caution is necessary when interpreting the findings.

Although this study was able to compare students' overall academic performance between the two formats, it was difficult to identify whether a relationship exists between online activities (such as viewing instructional videos, PowerPoint lecture notes, and podcasts) and student success. The authors were not able to track how many times a student viewed course resources as some were shared through open/unrestricted access. Future studies may be able to overcome this limitation by (1) restricting access to all course materials to the course management system and (2) by documenting the length of time students spend viewing online activities.

It is important to note that the current study is based on class sizes of approximately 20-25 students; therefore, the results may not be transferable when the learning environment represents class sizes of 100 or more students.

Because an assessment of students' prior knowledge was not conducted at the beginning of each class during the study period, there was no determination as to whether there were baseline differences in student ability between the two formats, a limitation that can be overcome by administering pre- and posttest for comparison purposes.

\section{Conclusion}

As noted in the reviewed literature, the flipped classroom has grown in popularity as it harnesses such benefits as active/participatory learning, enhanced use of interactive technology, and increased interactions between and among faculty and students (Flumerfelt \& Green, 2013; Hamdan \& McKnight, 2013; Smith, 2013).

The current study set out to compare the academic performance of students in both the traditional face-to-face format and the flipped classroom approach. The results, while consistent with the predominance of the current literature reviewed, indicate that the method of instruction impacted academic performance with students in the flipped sections outperforming their counterparts in the traditional sections.

The current literature provides limited insight into (1) differences among teaching environments and scenarios, (2) the value of using videos and podcasts as an instructional method, and (3) the academic cost and time to deliver a course using the flipped classroom approach. These issues may be explored through continued research and teaching.

\section{References}

Alvarez-Bell, R. (2014). Flipped classroom pilot in general chemistry II. Teaching with Technology, East Carolina University, page 1.

Bergmann, J., \& Sams, A. (2012). How the flipped classroom is radically transforming learning. Retrieved from http://www.thedailyriff.com/articles/how-the-flipped-classroom-is-radically-transforminglearning-536.php

Berrett, D. (2012). How 'flipping' the classroom can improve the traditional lecture. Chronicle of Higher Education, 58(25), A16.

Bishop, J., \& Verleger, M. (2013). The flipped classroom: A survey of the research. 120th American Society for Engineering Education National Conference Proceedings, Atlanta, Georgia, 1-18. 
Burke, S., \& Cody, W. (2014). Podcasting in undergraduate nursing programs. Nurse Educator, 39(5), 256259.

Butt, A. (2014). Student views on the use of a flipped classroom approach: Evidence from Australia. Business Education \& Accreditation, 6(1), 33-44.

Copley, J. (2007). Audio and video podcasts of lectures for campus-based students: Production and evaluation of student use. Innovations in Education \& Teaching International, 44(4), 387-399.

Enfield, J. (2013). Looking at the impact of the flipped classroom model of instruction on undergraduate multimedia students at CSUN. TechTrends, 57(6), 14-27.

Flumerfelt, S., \& Green, G. (2013). Using lean in the flipped classroom for at risk students. Educational Technology \& Society, 16(1), 356-366.

Franciszkowicz, M. (2008). Video-based additional instruction. Journal of the Research Center for Educational Technology, 4(2) 5-14.

Frederickson, N., Reed, P., \& Clifford, V. (2005). Evaluating web-supported learning versus lecture-based teaching: Quantitative and qualitative perspectives. Higher Education, 50(4), 645-664.

Fulton, K. (2012) Upside down and inside out: Flip your classroom to improve student learning. Learning \& Leading with Technology, 39(8), 12-17.

Gannod, G., Burge, J., \& Helmick, M. (2008). Using the inverted classroom to teach software engineering. Proceedings of the 30th International Conference on Software Engineering (pp. 777-786). Leipsig, Germany.

Hamdan, N., \& McKnight, P. (2013). The flipped learning model: A white paper based on the literature review titled a review of flipped learning. Flipped Learning Network.

He, Y., Swenson, S., \& Lents, N. (2012). Online video tutorials increase learning of difficult concepts in an undergraduate analytical chemistry course. Journal of Chemical Education, 89, 1128-1132.

Johnson, L. \& Renner, J. (2012). Effect of the flipped classroom model on secondary computer applications course: Student and teacher perceptions, questions and student achievement (Doctoral Dissertation, University of Louisville). Retrieved from: https://theflippedclassroom.files.wordpress.com/2012/04/johnson-renner-2012.pdf

Kay, R., \& Kletskin, I. (2012). Evaluating the use of problem-based video podcasts to teach mathematics in higher education. Computers \& Educations, 59, 619-627.

Lape, N., Levy, R., \& Yong, D. (2014). Can flipped classrooms help students learn? We're trying to find out. SLATE. Retrieved from:

http://www.slate.com/articles/technology/future tense/2014/04/flipped_classrooms_can_they_help_stu dents learn.html

Long, S., \& Edwards, P. (2010). Podcasting: Making waves in millennial education. Journal for Nurses in Staff Development, 26(3), 96-101.

Marshall, H. (2013). Three reasons to flip your classroom. Retrieved from http://www.slideshare.net/lainemarsh/3-reasons-to-flip-tesol-2013-32113

McGarr, O. (2009). A review of podcasting in higher education: Its influence on the traditional lecture. Australasian Journal of Educational Technology, 25(3), 309-321.

Milman, N. (2012). The flipped classroom strategy: What is it and how can it be used? Distance Learning, $9(3), 85-87$.

Moravec, M., Williams, A., Aguilar-Roca, N., \& O'Dowd, D. (2010). Learn before lecture: A strategy that improves learning outcomes in a large introductory biology class. CBE Life Science Education, 9, 473481. 
National Science Foundation. (2008). Fostering learning in the networked world: The cyberlearning opportunity and challenge. Arlington, VA: NSF. Retrieved February 20, 2015 from http://www.nsf.gov/pubs/2008/nsf08204/nsf08204.pdf

Papadapoulos, C., \& Roman, A. (2010). Implementing an inverted classroom model in engineering statistical: Initial results. American Society for Engineering Statistics. Proceedings of the 40th ASEE/IEEE Frontiers in Education Conference, Washington, DC, October 2010.

Pierce, R., \& Fox, J. (2012). Vodcasts and active-learning exercises in a "flipped classroom" model of renal pharmacotherapy module. American Journal of Pharmaceutical Education, 76(10), 1-5.

Poon, J. (2013). Blended learning: An institutional approach for enhancing student's learning experiences. MERLOT Journal of Online Learning \& Teaching, 9(2), 271-289.

Roehl, A. (2013). Bridging the field trip gap: Integrating web-based video as teaching and learning partner in interior design education. Journal of Family and Consumer Sciences, 105(10, 42-46.

Ruddick, K. (2012). Improving chemical education from high school to college using a more hands-on approach. Unpublished doctoral dissertation, University of Memphis.

Smith, D. (2013). Students' attitudes toward flipping the general chemistry classroom. Chemistry Education Research and Practice, 14, 607-614.

Strayer, J. (2012). How learning in an inverted classroom influences cooperation, innovation, and task orientation. Learning Environments Research, 15, 171-193.

Talbert, R. (2012). Inverted classroom. Colleagues, 7(1), 1-3.

Tune, J., Sturek, M., \& Basile, D. (2013). Flipped classroom model improves graduate student performance in cardiovascular, respiratory, and renal physiology. Advances in Physiology Education, 37, 316-320.

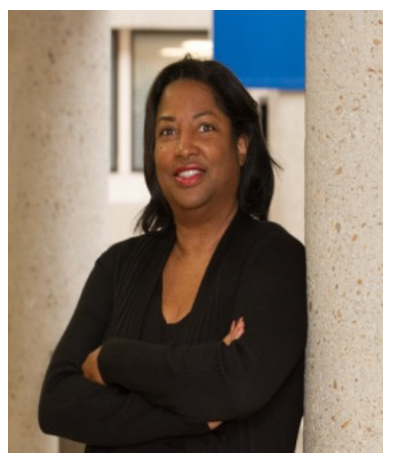

\section{Biographies}

Dr. Retta Guy has an Ed.D. in Curriculum and Instruction with emphasis in Instructional Systems Design from the University of Kentucky. She currently serves as Interim Associate Dean in the College of Business and is a tenured Professor in the Department of Business Information Systems at Tennessee State University. Dr. Guy's scholarly publications include an authored book entitled "The Digitally Disinterested," three edited books, 6 book chapters, 30+ articles, and 10 refereed proceedings to date. Dr. Guy's intellectual interests include the use of digital technologies to augment teaching and learning, instructional design and assessment, as well as distance learning with specific emphasis in hybrid, online and mobile teaching and learning.

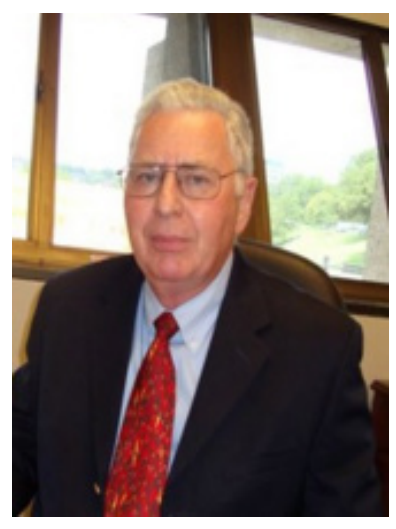

Dr. Gerald Marquis is a Professor at Tennessee State University in the Business Information Systems Department in the College of Business. He received his Ph.D. from Texas Tech University in the area of Information Systems. He has been teaching computer information systems courses for over thirty years. Prior to his teaching, Dr. Marquis worked for over fifteen years in the areas of manufacturing, banking, and system software development. His research interests include systems analysis, systems design, and database systems. Dr. Marquis has supported the efforts of the Office of Business and Economic Research through the design and implementation of databases to manage their accumulated data. 